\title{
Importance of airflow obstruction after thoracoplasty
}

\author{
M S PHILlips, M R MILlER, W J M KINNEAR, S E GOUGH, J M SHNEERSON \\ From Papworth Hospital, Papworth Everard, Cambridge
}

ABSTRACT Thirty six patients previously treated for pulmonary tuberculosis by thoracoplasty were studied to determine the prevalence and effect of airflow obstruction. The mean (SD) FEV was $_{1 \cdot 3}$ $(0.65) 1$ and the mean forced expiratory ratio (FER) $64 \%(12 \%)$. FEV $_{1}$ was less than predicted in every patient whereas FER was less than predicted in 30, being below the lower 98th percentile in $15(42 \%)$. In the 18 patients who complained of breathlessness the means of the standardised residuals (SR) for FEV 1 , peak expiratory flow (PEF), and FER were significantly lower and that for residual volume/total lung capacity (RV/TLC) significantly higher than those for the 18 patients who were not breathless (all $\mathrm{p}<0.0001$ ). There was no difference in the smoking history of the two groups. Only three of the 23 patients in whom reversibility of airflow obstruction was assessed showed a greater than $25 \%$ increase in PEF. None showed an increase in $\mathrm{FEV}_{1}$ of greater than $15 \%$. The 18 who were breathless had significantly lower values of arterial oxygen tension $\left(\mathrm{PaO}_{2}\right)$ and higher values of arterial carbon dioxide tension $\left(\mathrm{PaCO}_{2}\right)(\mathrm{p}<0.0001)$. Thirteen of these patients were in chronic respiratory failure $\left(\mathrm{PaO}_{2}<8.0 \mathrm{kPa}\right.$ or $\mathrm{PaCO}_{2}>5.9 \mathrm{kPa}$, or both) compared with only one of the 18 who were not breathless. The indices correlating best with $\mathrm{PaO}_{2}$ and $\mathrm{PaCO}_{2}$ were SR FEV 1 and SR PEF respectively. SR FEV 1 accounted for $34 \%$ of the variance in $\mathrm{PaO}_{2}$ and SR PEF for $29 \%$ of the variance in $\mathrm{PaCO}_{2}$. Airflow obstruction has been found to be common in patients with a thoracoplasty and to be associated with hypoxia and hypercapnia.

Many patients who were treated for pulmonary tuberculosis by thoracoplasty in the prechemotherapy era are now breathless. ${ }^{1}$ Some of them develop respiratory failure ${ }^{2}$ or cor pulmonale. ${ }^{3}$ These complications may even occur in patients with a thoracoplasty who were not previously breathless and who were leading apparently normal lives. ${ }^{4}$ The reasons why some patients are affected while others remain well have not been elucidated. A restrictive ventilatory defect is inevitable after thoracoplasty ${ }^{56}$ and there is some evidence that hypercapnia is related to decreased inspiratory muscle strength. ${ }^{7}$ Because several studies from the prechemotherapy era suggested that airflow obstruction was common in patients with pulmonary tuberculosis, ${ }^{8-10}$ we studied a group of patients treated for tuberculosis by thoracoplasty to determine the prevalence of airflow obstruction, its possible mechanisms, and its clinical importance in determining breathlessness and respiratory failure in these patients.

Address for reprint requests: Dr MS Phillips, Papworth Hospital, Papworth Everard, Cambridge, CB3 8RE.

Accepted 6 January 1987

\section{Subjects and methods}

We studied 36 patients who had previously been treated for pulmonary tuberculosis by thoracoplasty. They were divided into two groups. The first group of 18 (10 men, 8 women) had sought medical attention in recent years because of breathlessness. Seven were known to have suffered episodes of hypercapnic respiratory failure. The other group of 18 (13 men, 5 women) attended a chest clinic for follow up of their pulmonary tuberculosis. On direct questioning none of these admitted to breathlessness. Two of the breathless patients and one of the others were shown to be atopic by skinprick testing with common allergens.

Forced expiratory volume in one second $\left(\mathrm{FEV}_{1}\right)$ and forced vital capacity (FVC) were measured with a Vitalograph spirometer and peak expiratory flow (PEF) using a Wright mini peak flow meter. In 12 of the breathless patients and 11 of the others all three measurements were repeated 10 minutes after the inhalation of $800 \mu \mathrm{g}$ isoprenaline. Total lung capacity (TLC) and residual volume (RV) were measured with a PK Morgan whole bodiy plethysmograph; a Morgan transfer test model $\mathrm{C}$ was used to measure trans- 
fer factor for carbon monoxide (TLCO) and transfer coefficient (KCO). One patient could not undergo plethysmography and eight could not satisfactorily complete the measurement of transfer factor, owing either to difficulty with breath holding or to a low FVC. Arterial oxygen $\left(\mathrm{PaO}_{2}\right)$ and carbon dioxide tensions $\left(\mathrm{PaCO}_{2}\right)$ were measured with the patient at rest and breathing room air. Respiratory failure was defined as a $\mathrm{PaO}_{2}$ of less than $8.0 \mathrm{kPa}$ or a $\mathrm{PaCO}_{2}$ of greater than $5.9 \mathrm{kPa}$, or both.

Details of smoking habits were taken from each patient. The number of ribs resected was assessed from a chest radiograph. The degree of scoliosis was measured from a radiograph of the thoracic spine by the method described by Cobb. ${ }^{11}$

All statistical procedures were carried out on a microcomputer with validated algorithms. Predicted values for all the indices of lung function were calculated for each subject from standard regression equations ${ }^{12}$ and the degree of deviation from normality was expressed in terms of standardised residuals (SR), each SR being given by

$$
\mathrm{SR}=\text { (recorded }- \text { predicted }) / \mathrm{RSD} \text {, }
$$

where RSD is the residual standard deviation for the regression equation.

The results were expressed in this way to eliminate differences caused by the variation in age, sex, and height among the patients. An SR less than -2 means that the index value is below the lower estimated 98th percentile for that index. ${ }^{13}$ The means of the standardised residuals for each index of lung function from the two groups were compared by the use of an unpaired $t$ test. The relationship between standardised residuals for each index of lung function and both $\mathrm{PaO}_{2}$ and $\mathrm{PaCO}_{2}$ was determined by a Spearman's rank correlation procedure. A multiple linear regression procedure using standardised residuals to

predict $\mathrm{PaO}_{2}$ and $\mathrm{PaCO}_{2}$ was performed to determine which of all the independent variables were the best predictors of $\mathrm{PaO}_{2}$ and $\mathrm{PaCO}_{2}$. A $5 \%$ level of significance was set for acceptance of a regression coefficient based on $t$ ratio determinations. The percentage change in $\mathrm{FEV}_{1}$ and PEF after inhalation of bronchodilator was assessed by a comparison of means of the two groups in an unpaired $t$ test.

\section{Results}

The mean (SD) $\mathrm{FEV}_{1}$ for the 36 patients was $1 \cdot 30$ $(0.65)$ litres while the mean FVC was $2.00(0.83) 1$. The $\mathrm{FEV}_{1}$ was below predicted in all the patients and more than 2 standard deviations below the predicted value in $27(75 \%)$. FVC was below predicted in all but one. Because these patients have reduced lung volumes as a consequence of their thoracoplasty a reduced $\mathrm{FEV}_{1}$ does not necessarily reflect airflow obstruction, and forced expiratory ratio (FER) may be a better measure. The mean (SD) FER was $64 \%$ $(12 \%)$. FER was below predicted in $30(83 \%)$ of the patients and more than 2 standard deviations below predicted in $15(42 \%)$.

There was no difference in age, number of ribs resected, or degree of scoliosis between the 18 patients who were breathless and the 18 who were not. The two groups are compared in tables 1 and 2 .

The means of the SRs for FEV 1 , FVC, FER, and PEF were all significantly more negative and those for RV and RV/TLC both significantly more positive in the patients who were breathless.

There was little reversibility of airflow obstruction after inhalation of bronchodilator. No patient showed an increase in $\mathrm{FEV}_{1}$ of more than $15 \%$, though three showed an increase in PEF of more than $25 \%$. The percentage changes in FEV 1 and PEF

Table 1 Comparison of the breathless and non-breathless patients (values are means with standard deviations in parentheses, except for "never smoked")

\begin{tabular}{|c|c|c|c|c|c|}
\hline \multirow{5}{*}{$\begin{array}{l}\text { Age (years) } \\
\text { Height (metres) } \\
\text { No of ribs resected } \\
\text { Scoliosis (degrees, Cobb angle) } \\
\text { Lifetime cigarette consumption } \\
\text { (pack years) } \\
\text { Duration of cigarette smoking } \\
\text { (years) } \\
\text { Never smoked (\%) } \\
\% \text { change with bronchodilator } \\
\text { FEV } \\
\mathrm{PEF}_{1} \\
\mathrm{PaO}_{2} \text { (kPa) } \\
\mathrm{PaCO}_{2} \text { (kPa) }\end{array}$} & \multicolumn{2}{|c|}{ Breathless } & \multicolumn{2}{|c|}{ Non-breathless } & \multirow{2}{*}{$\begin{array}{l}\text { Significance } \\
\text { NS } \\
\text { NS } \\
\text { NS } \\
\text { NS }\end{array}$} \\
\hline & $\begin{array}{c}65 \cdot 0 \\
1 \cdot 69 \\
7 \cdot 2 \\
27\end{array}$ & $\begin{array}{l}(6.5) \\
(0.13) \\
(1 \cdot 7) \\
(15)\end{array}$ & $\begin{array}{c}62.9 \\
1.67 \\
7 \cdot 0 \\
23\end{array}$ & $\begin{array}{l}(5.9) \\
(0.07) \\
(1.5) \\
(13)\end{array}$ & \\
\hline & 19 & (19) & 19 & (20) & NS \\
\hline & $\begin{array}{l}22 \\
33\end{array}$ & (19) & $\begin{array}{l}25 \\
22\end{array}$ & (19) & NS \\
\hline & $\begin{array}{r}4 \cdot 2 \\
12 \cdot 0 \\
8 \cdot 4 \\
6 \cdot 6\end{array}$ & $\begin{array}{r}(4.5) \\
(11.4) \\
(1.8) \\
(1.0)\end{array}$ & $\begin{array}{r}4 \cdot 1 \\
9 \cdot 3 \\
10 \cdot 6 \\
5 \cdot 4\end{array}$ & $\begin{array}{r}(4.8) \\
(11.6) \\
(1.2) \\
(0.4)\end{array}$ & $\begin{array}{l}\text { NS } \\
\text { NS } \\
* \\
*\end{array}$ \\
\hline
\end{tabular}

*p $<0.0001$; NS - no significant difference at the $5 \%$ level.

PEF-peak expiratory flow

Conversion: SI to traditional units-blood gas tensions: $1 \mathrm{kPa}=7.5 \mathrm{~mm} \mathrm{Hg}$. 
Table 2 Comparison of absolute values and standardised residuals (SRs) for each index of lung function between the breathless and non-breathless patients (means with standard deviations in parentheses)

\begin{tabular}{|c|c|c|c|c|c|c|c|c|}
\hline \multirow[b]{3}{*}{$\begin{array}{l}\text { FEV }_{1}(1) \\
\text { FVC }(1) \\
\text { FER }(\%) \\
\text { PEF }\left(1 \mathrm{~min}^{-1}\right) \\
\text { TLC (l) } \\
\text { RV (l) } \\
\text { RV/TLC }(\%) \\
\text { TLCO }\left(\mathrm{mmol} \mathrm{min}^{-1} \mathrm{kPa}^{-1}\right) \\
\operatorname{KCO}\left(\mathrm{mmol} \mathrm{min}^{-1} \mathrm{kPa}^{-1} \mathrm{l}^{-1}\right)\end{array}$} & \multicolumn{4}{|c|}{ Breathless } & \multicolumn{4}{|c|}{ Non-breathless } \\
\hline & \multicolumn{2}{|c|}{ Absolute value } & \multicolumn{2}{|l|}{$S R$} & \multicolumn{2}{|c|}{ Absolute value } & \multicolumn{2}{|l|}{$S R$} \\
\hline & $\begin{array}{c}0 \cdot 88 \\
1 \cdot 59 \\
56 \\
190 \\
4 \cdot 00 \\
2 \cdot 40 \\
60 \\
5 \cdot 2 \\
1.8\end{array}$ & $\begin{array}{l}(0 \cdot 39) \\
(0 \cdot 70) \\
(12) \\
(78) \\
(1 \cdot 56) \\
(0 \cdot 97) \\
(8) \\
(0 \cdot 8) \\
(0 \cdot 4)\end{array}$ & $\begin{array}{r}-3.98 \\
-3.35 \\
-2.92 \\
-3 \cdot 57 \\
-2.93 \\
0.44 \\
3.63 \\
-2.60 \\
0.31\end{array}$ & $\begin{array}{l}(0.98) \\
(1.07) \\
(1.77) \\
(1.09) \\
(1.68) \\
(1.90) \\
(1.41) \\
(0.86) \\
(1.25)\end{array}$ & $\begin{array}{c}1 \cdot 75 \\
2 \cdot 47 \\
72 \\
333 \\
4 \cdot 32 \\
1.92 \\
45 \\
6 \cdot 3 \\
1.8\end{array}$ & $\begin{array}{c}(0 \cdot 57) \\
(0 \cdot 78) \\
(6) \\
(105) \\
(0.97) \\
(0.56) \\
(11) \\
(1.9) \\
(0.4)\end{array}$ & $\begin{array}{r}-2.21 \\
-1.95 \\
-0.62 \\
-1.64 \\
-2.53 \\
-0.83 \\
1.07 \\
-1.55 \\
-0.21\end{array}$ & $\begin{array}{l}(0.78) \dagger \\
(0.86) \dagger \\
(0.93) \dagger \\
(1.09) \dagger \\
(0.93){ }^{\dagger} \mathrm{NS} \\
(1.45)^{*} \\
(1.93) \dagger \\
(1.07)^{*} \\
(1.02) \mathrm{NS}\end{array}$ \\
\hline
\end{tabular}

${ }^{*} \mathrm{p}<0.01 ; \mathrm{tp}<0.0001$; NS - no significant difference at the $5 \%$ level (comparison of means of SRs in unpaired $t$ test). FVC-forced vital capacity; FER - forced expiratory ratio; PEF-peak expiratory flow; TLC-total lung capacity; RV-residual volume; TLco-transfer factor for carbon monoxide; Kco-transfer coefficient.

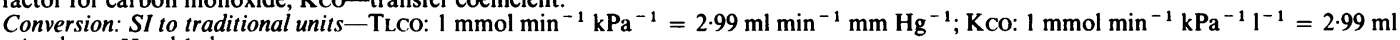
$\min ^{-1} \mathrm{~mm} \mathrm{Hg}^{-1} \mathrm{I}^{-1}$.

among the breathless patients were not significantly different from those observed in the patients who were not breathless.

The breathless patients showed significantly lower values of $\mathrm{PaO}_{2}$ and higher values of $\mathrm{PaCO}_{2}$. Thirteen $(72 \%)$ of them were in respiratory failure compared with one of those who were not breathless.

Comparison of the smoking habits of the groups did not reveal any differences in lifetime cigarette consumption in pack years or duration of cigarette smoking, or in the numbers who had never smoked. The mean (SD) SR FER for the 10 who had never smoked was $-1.86(1.81)$, which was not significantly different from that of the 26 smokers, $-1.74(1.85)$.

The rank correlations between the SRs for each index of lung function and $\mathrm{PaO}_{2}$ and $\mathrm{PaCO}_{2}$ are shown in table 3. On the basis of multiple linear regression and a stepwise inclusion procedure, the only predictors for $\mathrm{PaO}_{2}$ and $\mathrm{PaCO}_{2}$ were SR FEV 1 and SR PEF respectively. There was a positive correlation between $\mathrm{PaO}_{2}$ and $\mathrm{SR} \mathrm{FEV}_{1}$ and a negative correlation between $\mathrm{PaCO}_{2}$ and SR PEF. None of the other variables had a significant regression coefficient after

Table 3 Coefficients for rank correlations between the standardised residuals for the indices of lung function and arterial oxygen $\left(\mathrm{PaO}_{2}\right)$ and carbon dioxide tensions $\left(\mathrm{PaCO}_{2}\right)$

\begin{tabular}{llll}
\hline & $n$ & $\mathrm{PaO}_{2}$ & $\mathrm{PaCO}_{2}$ \\
\hline FEV & & $0.57 \ddagger$ & $-0.60 \ddagger$ \\
FVC & 36 & $0.54 \ddagger$ & $-0.52 \ddagger$ \\
FER & 36 & $0.43 \ddagger$ & $-0.53 \ddagger$ \\
PEF & 36 & $0.39^{*}$ & $-0.60 \ddagger$ \\
TLC & 36 & $0.20 \mathrm{NS}$ & $-0.07 \mathrm{NS}$ \\
RV & 35 & $-0.15 \mathrm{NS}$ & $0.18 \mathrm{NS}$ \\
RV/TLC\% & 35 & $-0.57 \ddagger$ & $0.41^{*}$ \\
TLCO & 35 & $0.20 \mathrm{NS}$ & $-0.35 \mathrm{NS}$ \\
KCO & 28 & $-0.21 \mathrm{NS}$ & $-0.20 \mathrm{NS}$ \\
\hline
\end{tabular}

${ }^{*} \mathrm{p}<0.05 ; \mathrm{tp}<0.01 ; \ddagger 0.001 ;$ NS-no significant difference at the $5 \%$ level. Abbreviations as in table 2 . these indices had been included in the regression equation. This indicates the multicollinearity of these 3 lung function indices. The SR for $\mathrm{FEV}_{1}$ explained $34 \%$ of the variance in $\mathrm{PaO}_{2}$ and that for PEF $29 \%$ of $\vec{\bullet}$ the variance in $\mathrm{PaCO}_{2}$. Figure 1 plots $\mathrm{FEV}_{1}$ (absolute ${ }^{\infty}$ values) against $\mathrm{PaO}_{2}$ for all 36 patients and figure 2. PEF against $\mathrm{PaCO}_{2}$, to give an indication of the spread of the data.

\section{Discussion}

We have found that $42 \%$ of these patients previously $\overrightarrow{\vec{O}}$ treated for tuberculosis by thoracoplasty have airflow obstruction as shown by an FER below the lower

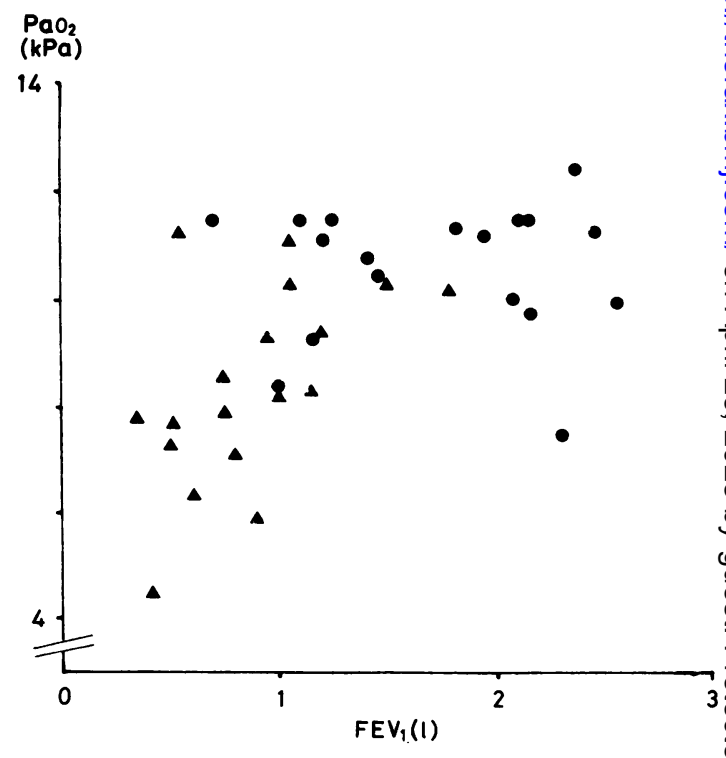

Fig 1 Arterial oxygen tension $\left(\mathrm{PaO}_{2}\right)$ plotted against $\mathrm{FEV} \mathrm{V}_{1} \underset{\mathrm{\sigma}}{\mathrm{Q}}$ in breathless $(\mathbf{\Delta})$ and non-breathless (O) patients. 


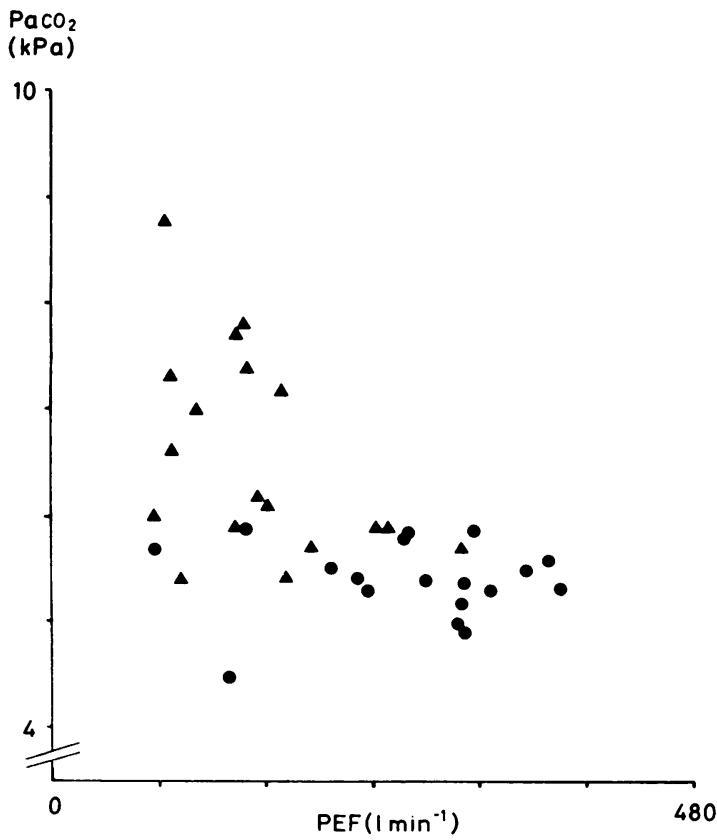

Fig 2 Arterial carbon dioxide tension $\left(\mathrm{PaCO}_{2}\right)$, plotted against peak expiratory flow $(P E F)$ in breathless $(\Delta)$ and non-breathless (O) patients.

98th percentile. $\mathrm{FEV}_{1}$ was below this limit in $75 \%$ of the patients but in the presence of a reduced FVC due to the thoracoplasty this does not necessarily reflect airflow obstruction. In patients such as these a low FER is a better guide to airflow obstruction than $\mathrm{FEV}_{1}$ alone.

Lancaster and Tomashefski found that airflow obstruction was common in patients with chronic pulmonary tuberculosis during the thoracoplasty era. ${ }^{8}$ They measured $\mathrm{FEV}_{1}$, maximum mid expiratory flow rate, maximum breathing capacity, and RV/TLC ratio and found airflow obstruction in $51 \%$ of their patients. Gaensler and Lundgren ${ }^{9}$ and Hallet and Martin $^{10}$ recorded prevalence rates for airflow obstruction of $43 \%$ and $34 \%$ among their patients.

The mechanism of this airflow obstruction is uncertain. Diffuse bronchial wall fibrosis due to tuberculous endobronchitis, ${ }^{14}$ paracicatricial emphysema, ${ }^{15}$ and occasionally stenosis of a single large bronchus have been suggested as causes. Smoking related emphysema and chronic obstructive bronchitis may have become important in some patients in recent years. We found no difference in cigarette consumption, however, between our breathless patients who had severe airflow obstruction and those who were not breathless, in whom it was not as severe. Nor was there any difference in airflow obstruction between smokers and those who had never smoked. Coexisting asthma will also worsen airflow obstruction but there are no studies of the prevalence of asthma among patients treated by thoracoplasty. In our study appreciable reversible airflow obstruction was uncommon, although in $13 \%$ of those in whom it was assessed PEF increased by more than $25 \%$ after inhalation of bronchodilator.

In our patients SR FEV was the best predictor of $\mathrm{PaO}_{2}$ and SR PEF was the best predictor of $\mathrm{PaCO}_{2}$. In the only previous study of patients treated by thoracoplasty ${ }^{16}$ Huang and Lyons found that respiratory failure best related to a low FVC and that $\mathrm{FEV}_{1}$ and PEF were not important. Their patients, however, had all been treated by thoracoplasty as a procedure supplementary to pneumonectomy, so they are not strictly comparable with our patients, none of whom had had a pneumonectomy.

The pathophysiology of respiratory failure in patients with a thoracoplasty should provide an explanation for the observation that these patients frequently deteriorate suddenly, sometimes without apparent reason, having previously led seemingly normal lives. ${ }^{4}$ All patients with a thoracoplasty have a restrictive ventilatory defect, ${ }^{56}$ to which many factors contribute. Lung volumes are reduced by collapse of functioning lung tissue at the time of operation and lung compliance is reduced by residual pulmonary fibrosis. Scoliosis, which is inevitable after unilateral thoracoplasty, ${ }^{17}$ reduces chest wall compliance. In some patients the skeletal deformity results in paradoxical chest wall movement, which interferes with the expansion of both lungs. ${ }^{18}$ In others pleural thickening limits expansion of the underlying lung, and we have found that its extent is related to $\mathrm{PaCO}_{2} \cdot{ }^{19}$ Inspiratory muscle function is impaired by the effect of resection of individual muscles and by the mechanical disadvantage at which those remaining must work because of the skeletal deformity.

Chronic airflow obstruction leads to hyperinflation, which may produce a beneficial fall in airflow resistance. ${ }^{20}$ This is offset, however, by the increase in work associated with breathing at high lung volumes. When airflow obstruction is superimposed on the restrictive ventilatory defect of patients with a thoracoplasty, this increase in work will be greater than usual because of the decreased respiratory compliance and impaired inspiratory muscle function. Respiratory compliance ${ }^{21}$ and respiratory muscle power ${ }^{22}$ decline with age, so that as these patients grow older their respiratory reserve will decrease and some will develop chronic asymptomatic respiratory failure. In all these patients a critical level may be reached at which a minor insult or small increase in airflow obstruction could precipitate life 
threatening ventilatory failure.

We conclude that airflow obstruction is a common finding in patients treated for pulmonary tuberculosis by thoracoplasty and in only a minority is there a reversible element. The severity of airflow obstruction relates to the development of respiratory failure; if this supervenes supportive treatment, such as assisted ventilation, ${ }^{23}$ may be required. We suggest that the presence and severity of airflow obstruction in patients with a thoracoplasty may help to identify those at greatest risk of developing respiratory failure.

We thank Drs JE Stark and TW Higenbottam for allowing us to study their patients and Miss Sally Smyth and Miss Jane Whiting for typing the manuscript.

\section{References}

1 Phillips MS, Kinnear WJM, Shneerson JM. Late sequelae of pulmonary tuberculosis treated by thoracoplasty. Thorax (in press-June).

2 Gaensler EA, Cugell DW, Lundgren I, Smith SS, Strieder JW. The role of pulmonary insufficiency in mortality and invalidism following surgery for pulmonary tuberculosis. J Thorac Surg 1955;29:163-87.

3 Zimmerman HA. Hemodynamics: studies on a group of patients who developed cor pulmonale following thoracoplasty. J Thorac Surg 1951;22:94-8.

4 Sawicka EH, Branthwaite MA, Spencer GT. Respiratory failure after thoracoplasty: treatment by intermittent negative pressure ventilation. Thorax 1983;38:433-5.

5 Cournand A, Richards DW. Pulmonary insufficiency. II. The effects of various types of collapse therapy on cardiopulmonary function. Am Rev Tuberc 1941;44:123-72.

6 Landis FB, Weisel W. Comparative study of pulmonary function loss: thoracoplasty versus small resection in surgery of tuberculosis. J Thorac Surg 1954;27:336-48.

7 Kinnear WJM, Phillips MS, Shneerson JM. Inspiratory muscle function after thoracoplasty [abstract]. Thorax 1986;41:244.
8 Lancaster JF, Tomashefski JF. Tuberculosis-a cause of $\stackrel{\searrow}{\times}$ emphysema. Am Rev Respir Dis 1962;87:435-7.

9 Gaensler EA, Lundgren I. Chronic bronchitis as an eti- $\mathscr{\sigma}$ ologic factor in obstructive emphysema. Am $\operatorname{Rev} \bar{O}$ Respir Dis 1959;80:185-93.

10 Hallet WY, Martin CJ. The diffuse obstructive pul- $\bar{\sigma}$ monary syndrome in a tuberculosis sanatorium. (1) $\stackrel{\nabla}{\mathbb{D}}$ Etiologic factors. Ann Intern Med 1961;54:1146-55.

11 Cobb JR. Outline for the study of scoliosis. Instructional $\mathrm{w}$ course lectures, American Academy of Orthopaedic $\overrightarrow{0}$ Surgeons. Vol 5. Ann Arbor: Edwards, 1948:261-75.

12 Quanjer PH. Standardised lung function testing. Eur $\vec{\omega}$ Bull Physiopathol Respir 1983;19(5, suppl):1-95.

13 Miller MR, Grove DM, Pincock AC. Time domain spi- $\overrightarrow{\vec{x}}$ rogram indices: their variability and reference values in non-smokers. Am Rev Respir Dis 1985;132:1041-8. N

14 Spain DM. Patterns of pulmonary fibrosis as related to $\omega$ pulmonary function. Ann Intern Med $\underset{\infty}{\stackrel{\omega}{\infty}}$ 1950;33:1150-63.

15 Dunnill MS. Pulmonary pathology. Edinburgh: Churchill $\stackrel{\circ}{\supset}$ Livingstone, 1982:93.

16 Huang CT, Lyons HA. Cardiorespiratory failure in patients with pneumonectomy for pulmonary tuberculosis: long term effects of thoracoplasty. $J$ Thorac $\overrightarrow{0}$ Cardiovasc Surg 1977;74:409-17.

17 Loynes RD. Scoliosis after thoracoplasty. J Bone Joint Surg 1972;54B:484-98.

18 Hauge BN. Diaphragmatic movement and spirometric volume in patients with one functioning lung. Scand $J \bar{O}$ Respir Dis 1971;52:84-99.

19 Moore NR, Phillips MS, Shneerson JM, Flower CDR, Dixon AK. Pleural thickening and skeletal deformity in thoracoplasty - the relationship to ventilatory failure [abstract]. Thorax 1986;41:717.

20 Pride NB, Green M. Abnormalities in respiratory mechanics. In: Scadding JG, Cumming G, Thurlbeck WM, eds. Scientific foundations of respiratory medicine. London: Heinemann, 1981:669-88.

21 Mittman C, Edelman NH, Norris AH, Shock NW. Re- @ٕ lationship between chest wall and pulmonary compli- $\bar{c}$ ance with age. J Appl Physiol 1965;20:1211-6.

22 Black LF, Hyatt RE. Maximal respiratory pressures: normal values in relationship to age and sex. Am Rev Respir Dis 1969;99:696-702.

23 Kinnear WJM, Shneerson JM. Assisted ventilation at home: is it worth considering? $\mathrm{Br} J$ Dis Chest 1985;79:313-51. 